\title{
The Conceptual Sphere of Red Square in the Poetry of Aleksandar Petrov
}

\author{
Dragana M. Ratković1,** \\ ${ }^{1}$ Serbian Language Institute of SASA, Belgrade, Serbia \\ *Corresponding author. Email: Dragana.Ratkovic@isj.sanu.ac.rs
}

\begin{abstract}
Aleksandar Petrov, Serbian-Russian poet, novelist scholar and university professor, is a cosmopolitan rooted in two cultural traditions (Serbian and Russian). The conceptual sphere of HOMELAND assumes a special position in his poetry. The aim of this paper is to analyse the conceptual sphere of RED SQUARE, the heart of Moscow, in the poetic cycle bearing the same name, which was the first cycle Petrov wrote in Russian (1972) and in his poem "Poetry in an Empty Dress" (1973) written in Serbian. While the conceptual sphere of RUSSIA is positive, involving emotions and nostalgia, the conceptual sphere of the RED SQUARE is negative i.e. associated with the criticism of Soviet Communist rule. The Red Square refers to the specific, Soviet aspect of Russia rather than to the Russia reaching beyond transitory political ideologies.
\end{abstract}

Keywords: conceptual sphere, home, homeland, Russia, Red Square

\section{INTRODUCTION}

Aleksandar Petrov was born in Serbia in 1938 to Russian parents who left Russia after the October Revolution and found refuge in Serbia (Yugoslavia). His mother Irina Ipolitovna Karateyev came to Serbia in 1920 as a student of the St. Petersburg Smolny Institute, established by Catherine the Great for girls of aristocratic lineage. The teachers and students of Smolny first evacuated to Harkov, and then both institutes, Smolny and Harkov, left the country. His father Nikolai Ivanovich Petrov, a young officer in the army of General Vrangel, came to Serbia in the same year. Irina and Nikolai met in Serbia, got married and had two children, Olga and Aleksandar, born in the thirties.

Petrov began writing and publishing poems in Serbian in the mid-fifties as a high-school student, while his first poetry book, written in Serbian, was published in Belgrade in 1971. He wrote his first poems in Russian in 1972 while he was in the US as a participant in the International Writing

*Fund: The article was funded by the Ministry of Education, Science and Technological Development in accordance with the agreement № 451-03-68 / 2020-14 / 200174 concluded with the Serbian Language Institute of the Serbian Academy of Sciences and Arts. The text has been partially taken from the book Poet and immigration: the conceptual sphere of $\mathrm{HOME}$ and HOMELAND in the poetry of Aleksandar Petrov, which was being prepare for printing when the call for the conference was announced.
Program of the University of Iowa. At that time he wrote a cycle of poems titled Red Square, which he later translated into Serbian. This cycle was published in various of his poetry collections, including those translated into other languages. The poems of Aleksandar Petrov have been translated into over thirty languages. Petrov has twenty books translated into various languages and published in fourteen countries. Many more of his books were published in Serbia.

The collected poems of Aleksandar Petrov have been published in The Fifth Side of the World, while his poems written in Russian are included in Here and There. [1], [2] It is important to note that in addition to several anthologies of contemporary Serbian poetry (in Serbian as well as in English and French translations) Petrov is also the author of two editions of an anthology of Russian poetry. [3], [4] Petrov made a re-evaluation of Russian, especially $20^{\text {th }} \mathrm{c}$. poetry. He included until then less known avant-garde poets and was the first to feature the oberiut poet Daniil Harms as well as Russian underground poets such as Igor Holyin and Henrih Sabgir. Joseph Brodsky wrote that Petrov, "a poet of considerable power himself" being also "a visiting scholar to various American campuses, a literati in the old-fashioned sense of the word" compiled "the most comprehensive anthology of Russian poetry to date". [5] 


\section{THE CONCEPTUAL SPHERE OF HOME AND HOMELAND}

The conceptual sphere of RED SQUARE can be viewed as a variant of the conceptual sphere of the HOMELAND, which is why it is necessary to discuss the conceptual sphere of the two homelands that Petrov perceived as his own - SERBIA and RUSSIA. However, we will first quote a part of Petrov's article elucidating the terms of analysis such as concept and conceptual sphere, which he himself used in his own studies of other poets in his well-known book The Canon. Serbian Poets of the $20^{\text {th }}$ Century:

"The term conceptual sphere, proposed by D.S. Likhachov, describes the conceptualization of the image of the world in the works of a certain poet, for example. In addition to conceptual sphere, scholars have also used terms such as conceptual field and conceptual system, mainly with the same or similar meaning. [6]

The term concept is not in fact new, but contemporary linguists, especially those engaged in linguistic research of culture and art, define it from new points of view. Although it is still basically identified as the contents or the meaning of a notion, V.A. Maslova highlights new and different interpretations of the concept. Concurring with other linguists, D.S. Likhachov purports that the concept results from the "clash" of the meaning of the word with the personal and national experience of the individual. Maslova accepts this interpretation as she observes that the meaning itself is "surrounded by an emotional and expressive halo, also involving values". [7] Some linguists view the structure of a concept as a sphere in which the basic meaning occupies the center, like the nucleus of an atom, while the periphery or orbit consists of connotations, associations and everything that has been added by culture, tradition, collective and individual experience.

Cognitive and artistic concepts are distinguished by the degree of wealth and variation of the periphery. In the case of artistic concepts, the periphery is highly individualized and psychologically more complex, involving variation of meanings, representations, emotions, expressions of will, as this outer circle is founded and built on the principle of association. In the work of art even ordinary words become concepts-symbols that may assume a key role in the creation of a personal reality, an image of the world and of the poetic text. The conceptual spheres of a variety of poets tend to be generated as specific combinations of some universal concepts and a number of concepts specific to the individual poet. There are universal concepts such as those of time and space, that can appear integrated in a chronotope, as defined by
Bakhtin, but also important specific concepts such as faith, death, love, homeland, nation...". [8]

V.A. Maslova, mentioned above by Petrov, wrote in her study on the conceptual sphere in the poetry of Marina Tsvetaeva that the work of every good poet is characterized by a few dozen favourite words-images, words-motifs or concepts, which keep recurring, thus enriching and transforming themselves. They contain the personal, intimate meaning, which only partly corresponds with the dictionary meaning. She claims that these are concepts that represent the core of the poetic work. In the poetry of Alexander Blok these are: STAR, ABYSS, GALE, MUSIC, SOUL, WILD, while Tsvetaeva uses the concepts of SPACE (HOME, GARDEN, MOSCOW, RUSSIA), 'time', 'death', 'separation', 'poet and poetry', 'dream', 'joy', 'silence', etc. [7] The following concepts are outstanding in the poetry of Aleksandar Petrov: SERBIA, KOSOVO, RUSSIA, RED SQUARE, THE BALKANS, ART, HISTORY, CHRISTIANITY, LOVE, THE EROTIC, LIFE, DEATH, HOME, HOUSE, CHURCH, BELL...

The concepts of HOME and HOMELAND in Petrov's poetic language are structured as multidimensional categories including various parameters (aspects): spatial (physical), sociohistorical, cultural, functional, institutional, ideological, emotional and axiological [9]. The basis of the concepts consists of spatial and social aspects, while other aspects also exist either within the basis, thus varying its profiles, or by organizing separate profiles (presented further in our analysis).

The analysis of the concept of HOMELAND in the poetic discourse of Aleksandar Petrov, derived from the cognitive and ethno-linguistic theoreticalmethodological aspect, highlights this poet as a member of the Serbian linguistic and cultural community with additional elements associated with emigration and cosmopolitanism. The linguistic and stylistic parameters of profiling a given concept in his poetic discourse largely have equivalents in the parameters that profile the concept of HOMELAND in Serbian language, culture, literary and religious discourse. As for Petrov's poetic discourse, the conceptual sphere of HOMELAND is also based on the lexical-semantic, creative, syntagmatic-paradigmatic and textual potential of the Serbian and Russian lexemes domovina, otadžbina, rodina, otčizna, strana, presented by physical, functional, social, axiological and emotional parameters; while stylistic variation neutralizes or abolishes some of the oppositions relevant to the stereotyping of this cultural concept ('one's own - other's', 'life - death', 'inner space - outer space'), stylistic achievements in profiling a given conceptual sphere are based on the individual point of view and personal 
perspective of the author. Petrov has not one, but two homeland: Serbia and Russia.

The poetry of Aleksandar Petrov presents various perspectives of the poet himself on his homeland. As his poetry is comprehensive and cosmopolitan in its orientation, it is difficult to determine a strong (basic) point in the poetic conceptualization of the homeland, having in mind that his entire poetry is essentially cosmopolitan. However, based on a careful analysis of his poetic discourse with regard to the point of view and perspective, three profiles of the poet's homeland can still be distinguished

SERBIA is recognized as the most elaborate concept of the poet's HOMELAND, which is presented in the poems as a multidimensional category with all aspects that are characteristic of the linguistic image of the world of Serbian language speakers (physical, social, cultural, historical, religious, emotional).

As a special profile of the poet's homeland within the concept of SERBIA as a HOMELAND, the point of view of the 'other', 'foreign', 'external' to his homeland stands out. As for the contrast of the points of view of 'one's own and 'other's, an emotional profile is generated.

The concept of RUSSIA as a HOMELAND LOST is idealized in the poet's view, so the emotional, cultural and historical aspects of the latter are most pronounced.

The concept of RUSSIA appears as a multiple space - geographical, ethnic, national, cultural and ideological. The spatial profile, which is the basis of this concept, generates the concept of the "national homeland" with its main values: name, language, history, and culture. Individual poetic factors (the poet's point of view and his poetic perspective) and socio-historical factors profile this concept through variation of its spatial aspects by means of axiological and emotional parameters, correlating it with the concept of SERBIA. Consequently, the question arises whether the poet perceives both countries as "his homeland" and whether he has the same relationship with them, i.e. which one is prioritized as the "real" homeland. The specific feature of the poet's literary shaping of Russia is reflected in the fact that he writes about it, but does not live in it. While the image of Serbia is based on his personal experience of living there, the image of Russia is based on his parents' stories and their personal experiences of Russia as their homeland, developed in the imagination of the poet during his childhood and later thanks to his readings of Russian literature in the original language.

The specific conceptualization of RUSSIA and SERBIA as HOMELAND is significantly defined by the motif of emigration. The concepts of MY HOMELAND IS RUSSIA and MY HOMELAND IS SERBIA refer to the members of the same family and are recognized in the following lines of the poem "In the Russian Church in Belgrade", translated by author:

Behind the church wall

There awaits for them [Russian emigrants]

An unburnt ship.

Home - for the boy.

Here the concepts shipt and home involve more meanings realized on the physical as well as on the social and pragmatic level. In addition, these lexemes metonymically represent the country, the state where the ship is located (an unburnt ship) or home, i.e. Serbia. Moreover, their use reflects the difference between the two generations of Russians in Serbia (those born in Russia and their descendants born in Serbia) and their respective perceptions of Serbia. The conceptualization of SERBIA as a HARBOUR, a TEMPORARY HOME refers to the members of the older generation of people born in Russia, who came to Serbia by ship and who perceive this country as a harbour which they entered in the hope of leaving it one day also by ship. In a word, it is a temporary dwelling place. On the other hand, the conceptualization of SERBIA as a PERMANENT HOME refers to the members of the second generation, or children of immigrants born in Serbia, who see this country as their real and only home - a homeland. This perception is the basis of the concepts HOME IS WHERE I WAS BORN and HOMELAND IS MY HOME. On the other hand, the concept of Petrov is profiled by the parameters of longing and hope of returning to the homeland (for Russian emigrants) and parameters of respecting the country that secured a refuge for the boy's family, thus providing him with a home.

The overlapping of the conceptual spheres of HOME, HOMELAND and RUSSIAN is characterized by the FAMILY HOME. HOME profiles the preservation of the Russian identity in the cultural and axiological aspects. The "Russianness" of the new home in Serbia is reflected in cherishing the Russian tradition, customs, stories about Russia that inspire the boy's imagination, the Russian language, ethnic and historical consciousness, standards and cultural symbols, specific Russian physiognomy, nature and temperament, as well as Russian names.

The overlapping of the conceptual spheres of HOME and NATIONAL HOMELAND (RUSSIA) is also characterized by the concept of the CHURCH as HOME. Namely, Petrov's poetry contains two homes in the socio-axiological sense - 
as places where the family community lives and perpetuates certain traditional, cultural, moral and other values. One of them is the place where the "immediate" family lives (a family home) while the other is the church as a social institution that brings together members of the same group, members of the "extended" family - the "native" home. In addition, Petrov's poetry features a dominant motif of the church in a foreign country (the Russian church in Serbia and the Serbian church in America). The conceptualization of the CHURCH as (native) HOME is based on spatial, sociohistorical, axiological, emotional and cultural parameters.

\section{THE CONCEPTUAL SPHERE OF RED SQUARE}

The Russian Orthodox Cathedral of St. Basil (Cathedral of Vasily the Blessed) at Red Square in Moscow, one of the best-known symbols of Russia, is not even mentioned in Petrov's cycle of poems Red Square. Why? Because Petrov wanted to present the image of Red Square as one of the symbols of the Soviet Union, a country completely different from pre-Revolutionary Russia (that had been the homeland of his parents and of the idealized Russia of his imagination and dreams). The clash of two images of Red Square, one overt, in which the Sun is buried, and another implied, in which his favorite poet Osip Mandelshtam tries to resurrect it, appears in the last poem of this cycle, "The Dream of Red Square", translated by the author.

I see a dream.

This is Red Square dreaming.

I am reading a poem on Red Square.

In my poem Mandelshtam sun

holding a shovel in his hands, is looking for the

buried in Red Square.

The clanging of his shovel

Wakes up Red Square. [10]

The distinguished Russian contemporary poet Evgeniy Bunimovich quotes lines from this poem in his introduction to Petrov's book of poetry in Russian The Fifth Side of the World:

"The ties of the poet with the homeland of his ancestors are too close and too complex. It would have been very difficult to publish in the USSR such a poem, written in 1972, in which

\section{Mandelshtam}

holding a shovel in his hands, is looking for the sun

\section{buried in Red Square.}

The clanging of his shovel

Wakes up Red Square.

It is not only a question of allusions to the forbidden name of the great poet who was in political disgrace and the ambiguous mention of the main square of the Soviet state. The whole point is in the unusual form of poetic expression. Because free verse, verse libre, even today, as is well known, often sounds strange and alien to the domestic ear educated on the chrestomaties of a syllabic-tone school program, while in those times it was generally perceived as nonsense if not as a conspiracy.

However, Aleksandar Petrov knows perfectly well the Russian poetic tradition in all its nuance". [11]

The poem "Red Cat" (translated by Krinka Vidaković Petrov and Mark Strand) effects an erotization of the proletarian concepts of hammer, sickle and red colored star, all featured on the Soviet flag, presenting them as parts of the female body, a red cat. Petrov proceeds in this way in order to provide a satirical rendering of their social function, which is of generating an optimistic opposition to everything negative, allegedly black, embodied in a nonexistent black cat:

On red Square is a black cat.

Someone has gone mad.

There are no more black cats.

On my bed is a red cat.

A pretty red cat.

It has a star on its stomach.

A flaming sickle under the star.

What can you do with a burning red cat?

Give the red cat to Red square. [10]

In the poem "Boy" (translated by Krinka Vidaković Petrov and Mark Strand) Petrov evoked the conceptual sphere of RED SQUARE by other poetic means:

A boy walks across Red Square.

He walks on his hands.

A boy sees the sky.

The sky is golden.

In the sky stands a cathedral.

An empty cathedral.

Only candles burn. 
The boy wants to cross himself

Or just wipe his forehead

Burning sweat from his forehead.

The boy falls unto Red Square.

On Red Square is a golden head. [10]

Physical and religious parameters are the basis for axiological parameters in the poem "Girl" (translated by Krinka Vidaković Petrov and Mark Strand), which is about a miracle taking place on the square:

A girl runs barefoot across Red Square.

Burning Red Square.

The girl's feet catch fire.

The girl begins to fly.

She flies over Red Square.

No one believes they see the girl.

For one who doesn't believe

There is no girl.

No girl. [10]

This no, emphasized by reiteration, refers to the objective visual perception, while the verb to believe, standing in antinomy to the expression in the previous line, refers to a miracle in which flying could be interpreted as an allusion to Christ's resurrection. However, Petrov's conceptual sphere of THE SOVIET RED SQUARE does not allow for any religious elements even if the miracle of resurrection were to happen in front of the eyes of a mass of people on the square.

Red Square also appears in "Poetry in an Empty Dress", a poem written in Serbian that is not part of the Red Square cycle. In the Russian language, the word for square (пломадь) is of feminine gender, used by the author to suggest a potential identification of poetry, the square and the female body. As one of Petrov's key poems, "Poetry in an Empty Dress" (translated by K. Vidaković Petrov and Mark Strand), was included in Contemporary East European Poetry: An Anthology:

A girl

A sphere

A square

A world

She is Red Square

She melts red wax

On the square
She is a bridge

Golden Gate of San Francisco

Open all hours

Day or night

Promiscuous gateway brilliant lovers

Endless lovers passing through

She is the marketplace

The Green Wreath of Belgrade

Smuggling nature into town

Advocating the equality

Of convolutions and corns

Stimulating the revolution

of red blood cells

Something like

High tension

Frantic grass a red pamphlet

Rum in a fresh strawberry

Dreams mere dreams

In fact an empty dress

Pants taken off

Clothes without owners

Worn but cleaned and pressed

She can be useful

On various occasions

Even the most solemn

Depending on what you want

Especially if you use the couch

Or are being used in any way [10], [12]

The red color, wax and its melting appear are physical parameters that profile the Red Square from an ideological perspective. The red color appears as a metaphor of communist ideology, the wax of the communist official ideological control, whose melting is an allusion to the process of destalinization initiated by Nikita Khrushchov. 
Poetry melting the red wax participates in this process: melting wax, just like melting the strongest steel, is a metaphor of the control under the seal of red ideology. Melting suggests liberation, a transfer from the state of solid into the state of soft, a dynamic process. Poetry is transfer, change, a leap, flight, movement. Poetry is the embodiment of red space, Красная площадь melting its own wax that had been solidified a long time ago. [13]

\section{CONCLUSION}

The conceptual sphere of RED SQUARE, as rendered by Petrov in this poem bearing a very unusual and provocative title, anticipated already in 1973 the radical changes that would take place in Russia towards the end of the 20th century. The poetry melting red wax on Red Square, as we read in "Poetry in and Empty Dress", is the underground Russian poetry of the seventies which Petrov supported and was the first to present in his anthology in a comprehensive way.

Petrov's conceptual sphere of RED SQUARE refers to Soviet ideological constraints imposed on Russia, while in other poems Russia asserts its permanency in contrast to the transitory nature of political ideologies.

\section{References}

[1] Petrov, A. The Fifth Side of the World. Collected, Russian and new poems. - Belgrade, 2013.

[2] Petrov, A. Here and There. - M., 2019.

[3] Petrov, A. Anthology of Russian Poetry 17-21 c. - Belgrade, 1977.

[4] Petrov, A. Anthology of Russian Poetry 17-21 c. - Belgrade, 2011.

[5] Petrov, A. Lady in an empty dress (aftherword by J. Brodsky). - Madrid, 1988.

[6] Likhachov, D.S. Conceptual sphere of Russian language. - M., 1997.

[7] Maslova, V.A. The conceptual sphere in the poetry of Marina Tsvetaeva. - M., 2004.

[8] Petrov, A. The Canon. Serbian Poets of the 20th Century. - Belgrade, 2008.

[9] Bartminski, J. Language - Image — World. - Belgrade, 2011.

[10] Petrov, A. Bound by Red. - Belgrade, 2003.

[11] Petrov, A. The Fifth Side of the World (introduction by E. Bunimovich). - M., 2013.

[12] Contemporary East European Poetry: An Anthology (edited by Emery George). - Oxford University Press, USA, 1994.

[13] Vidaković-Petrov, K. "The Whetstone: Body and Text," World and Century: literary work of Alexander Petrov. Belgrade, 2017, pp. 21-61. 